MEDIA ILMIAH TEKNIK SIPIL

Volume 6 Nomor 2 Juni 2018

Hal. 102-108

\title{
DASAR-DASAR PERTIMBANGAN PEMBANGUNAN JALAN KABUPATEN DI PROVINSI KALIMANTAN SELATAN
}

\author{
Noor Jasmani \\ Program Studi Teknik Pertambangan Politeknik Islam Syekh Salman Al-Farisi \\ Jl. Munggu Raya No.212 TambaranganKab. Tapin Prov. Kalimantan Selatan 71181 \\ Email: jasmani23@yahoo.co.id
}

\begin{abstract}
Abstrak
Mengimbangi peningkatan laju pertumbuhan lalu lintas berkaitan dengan pertumbuhan kepemilikan kendaraan yang angkanya jauh lebih besar dari perkembangan volume jalan, peningkatan pembangunan jalan baik dari segi kuantitasnya maupun kualitasnya pada pembahasan ini lebih dibahas pada sesi kualitasnya dalam hal penyiapan prasarana suatu jaringan jalan yang memadai termasuk di dalamnya sistem perencanaan perkerasan jalan, dalam penelitian ini fokusnya pada jalan kabupaten, jalan ini lebih khusus karena pengelolaannya dilakukan oleh pimpinan daerahnya setempat. Perencanaan suatu konstruksi perkerasan jalan yang efisien sesuai dengan tingkat kebutuhan lalu lintas sudah sewajarnya diperlukan, pada pelaksanaannya peran serta sumber daya manusia terkait dengan teknis perencanaan, pelaksanaan dan pengawasannya sangat membantu keberhasilan program ini.
\end{abstract}

Kata kunci : Volume Jalan, Sistem Perencanaan, Jalan Kabupaten, Perkerasan Jalan 


\section{PENDAHULUAN}

Jalan merupakan salah satu bentuk sistem transportasi darat yang melayani pergerakan lalu lintas yang harus terencana secara aman dan efisien. Menurut Undang-undang Republik Indonesia tentang Jalan, jalan mempunyai peranan yang penting dalam mewujudkan perkembangan kehidupan bangsa.

Dalam hubungannya dengan perekonomian dan sektor-sektor lainnya, perkembangan sektor-sektor tersebut akan sangat bergantung pada fungsi sistem jalan yang ada. Ketidakefektif-an sistem suatu jalan dapat menyebabkan terhentinya pertumbuhan ekonomi suatu daerah. Juga timbulnya permasalahan sosial dapat disebabkan karena rendahnya tingkat aksessibilitas. Dilain pihak, penyediaan sistem jalan yang baik tidak berarti menjamin terjadinya perkembangan dan pertumbuhan ekonomi yang tinggi, tanpa adanya sumber daya alam yang dapat diolah dan dikembangkan, termasuk sumber daya manusia-nya yang mampu mengolah dan mengembangkannya. Dalam hal ini jalan akan berfungsi maksimal jika didukung oleh sumbersumber tersebut.

Persyaratan dasar dari suatu jalan adalah tersedianya suatu lapisan perkerasan jalan yang memadai. Sebagaimana diketahui umumnya tanah dasar tidak dapat menerima secara langsung beban-beban lalu lintas tanpa adanya deformasi. Perkerasan jalan merupakan suatu struktur yang terletak antara tanah dasar dan roda kendaraan, yang berfungsi menyebarkan beban-beban lalu lintas ke tanah dasar tanpa melebihi kekuatan tanah dasar itu sendiri. Perkerasan tersebut diharapkan dapat menjamin keamanan dari pergerakan lalu lintas untuk masa yang cukup lama, dengan pemeliharaan yang sekecil-kecilnya.

Pemenuhan persyaratan tersebut sewajarnya tergantung dari keseimbangan tingkat kebutuhan lalu lintas, keadaan tanah dan iklim dan dengan tingkat dana pengadaan perkerasan tersebut.

\section{TINJAUAN PUSTAKA}

\section{Kondisi Umum Jalan yang Ada}

Sebagaimana diketahui, klasifikasi jalan dapat dibedakan antara lain menurut administrasi pemilikan, yaitu: jalan negara, jalan provinsi, jalan kota, jalan Kabupaten, dan jalan desa.
Khusus untuk jalan Kabupaten, jalan ini merupakan jalan yang dibuat dan dipelihara oleh Kabupaten, dengan ciri-ciri lalu lintas yang rendah.

Dengan meningkatnya pertumbuhan lalu lintas pada saat ini, selaras dengan era pembangunan berkelanjutan, maka dengan sendirinya kebutuhan kapasitas jalan akan meningkat.

Melihat kondisi umum jalan Kabupaten yang ada, sebagian dari jalan tersebut diperkirakan tidak dapat melayani kebutuhan lalu lintas pada masa mendatang, dikarenakan antara lain: beban lalu lintas yang meningkat, menurunnya nilai struktural perkerasan yang ada, kapasitas jalan yang tidak memadai (lebar jalan, termasuk lebar perkerasan dan bahu jalan).

Untuk mengantisipasi hal tersebut perlu diperhatikan sistem perencanaan perkerasan jalan yang terpadu, melalui proyek peningkatan jalan yang ada dan pembangunan jalan-jalan baru.

Untuk mencapai tujuan tersebut, khususnya pemilihan konstruksi perkerasan yang secara efisien sesuai dengan ciri kebutuhan lalu lintasnya, Bina Marga telah mengadakan suatu pedoman dalam merancang lapisan tebal perkerasan khususnya untuk jalan Kabupaten sehingga diperolehnya suatu kesamaan pedoman dalam pemilihan kriteria perencanaan.

Mengacu pada pedoman tersebut, yang diselaraskan dengan alih teknologi dan pengembangan sumber daya manusianya, diharapkan perencanaan perkerasan jalan Kabupaten dapat segera memasyarakat, khususnya dapat diterapkan bukan hanya oleh para perencana tetapi oleh staf kabupaten setempat.

Makalah ini pada dasarnya merupakan pertimbangan umum dalam perencanaan perkerasan untuk jalan Kabupaten, sebagai bahan informasi agar dapat dicapai pemilihan konstruksi perkerasan yang secara teknis dapat dipertanggungjawabkan.

\section{Pedoman Perencanaan Perkerasan Jalan Data Teknik Perencanaan}

Proses pertama dalam perencanaan teknik perkerasan jalan adalah diperlukannya data yang menunjang dalam pencapaian proses perencanaan. 
Data tersebut antara lain meliputi: data lalu lintas dan keadaan tanah.

\section{Lalu Lintas}

Data lalu lintas akan dipergunakan sebagai bahan masukan dalam penentuan parameter-para meter yang berkaitan dengan tebal perkerasan, seperti: kelas jalan, lebar perkerasan, banyak jalur lalu lintas, dan jenis perkerasan yang dipilih.

Pada hakekatnya data lalu lintas tersebut merupakan lalu lintas sepanjang rute yang akan direncanakan, meliputi volume dan komposisi lalu lintas dengan mempertimbangkan faktor pertumbuhan lalu lintas sebagai akibat bertambahnya jumlah perjalanan, perkembangan sosial dan ekonomi.

Untuk perencanaan jalan baru, data lalu lintas acuan dapat diperkirakan melalui data-data terakhir dari pos-pos perhitungan lalu lintas terdekat. Sedangkan untuk peningkatan jalan, maka pendataan lalu lintas dilaksanakan pada setiap ruas jalan yang dilalui kendaraan bermotor selama 2 (dua) hari dengan jangka waktu 12 (dua belas) jam an dicatatnya pada setiap 5 (lima) kilometer sepanjang ruas jalan tersebut.

\section{Keadaan Tanah}

Penyelidikan tanah dimaksudkan untuk menentukan sifat-sifat yang tepat dari tanah dalam hal kekuatan geser, gaya dukung dan pemadatan.

Perencanaan struktur lapis perkerasan direncanakan atas dasar kekuatan tanah dasar yang diambil pada suatu kadar air yang sama dengan kondisi kadar air yang paling basah yang terjadi sesudah konstruksi. Sehingga diperlukannya pengujian pemadatan standar dan CBR (California Bearing Ratio) di laboratorium khususnya bagi konstruksi perkerasan jalan baru. CBR ini merupakan pengujian penetrasi yang direncanakan untuk memperkirakan kapasitas dukung tanah pada lapis tanah dasar maupun lapis perkerasan.

Sedangkan untuk pekerjaan peningkatan jalan dilakukan dengan menggunakan metode yang lebih sederhana, yaitu dengan menggunakan pengukuran penetrasi CBR di lapangan dengan alat DCP yang merupakan alat sistem Penetrometer Kerucut Standar.

\section{METODE PENELITIAN}

\section{Perencanaan Teknik Perkerasan Jalan Struktur Lapis Permukaan}

Pada umumnya struktur lapis perkerasan jalan lentur terdiri dari lapis permukaan, lapis pondasi atas, lapis pondasi bawah dan tanah dasar.

Lapis permukaan merupakan lapisan yang terletak paling atas dari suatu struktur lapis perkerasan jalan, lapis ini berfungsi menahan beban roda yang secara langsung diterima dan disalurkan ke lapisan berikutnya, melindungi badan jalan dari pengaruh cuaca, dan merupakan lapisan penahan aus akibat dari beban lalu lintas.

Lapis pondasi atas merupakan lapis utama pembagi beban yang akan disalurkan ke lapisan berikutnya. Lapisan ini terletak secara langsung di bawah lapis permukaan.

Lapis pondasi bawah merupakan lapis kedua pembagi beban yang akhirnya disalurkan ke tanah dasar. Sesuai dengan letaknya, maka lapisan ini juga berfungsi sebagai lapis pertama agar pelaksanaan konstruksi jalan dapat berjalan dengan lancar, yang disebabkan lemahnya daya dukung tanah dasar terhadap peralatan pekerjaan jalan.

Tanah dasar merupakan lapisan yang memikul beban lalu lintas yang telah disebarkan oleh lapisan-lapisan di atasnya. Lapisan ini harus dipadatkan dengan baik agar dapat mendukung beban lalu lintas tersebut.

\section{Kelas Jalan}

Dalam menentukan tingkat penanganan jalan Kabupaten, diadakan klasifikasi kelas jalan yang didasarkan pada Lalu Lintas Harian Rata-rata (LHR) pada akhir umur rencana.

Dalam hal ini dapat pula ditentukan batasanbatasan lain yang diperlukan dalam perencanaan tebal perkerasan, seperti: lebar perkerasan jalan, banyak jalur dan persyaratan jenis permukaan.

Kelas-kelas jalan dari Bina Marga khusus untuk jalan Kabupaten, meliputi: 
Tabel 1. Kelas Jalan Untuk Jalan Kabupaten Menurut Bina Marga

\begin{tabular}{|c|c|c|c|l|}
\hline $\begin{array}{c}\text { Kelas } \\
\text { Rencana } \\
\text { Lalu } \\
\text { Lintas }\end{array}$ & LHR & $\begin{array}{c}\text { Lebar } \\
\text { Per- } \\
\text { kerasan }\end{array}$ & $\begin{array}{c}\text { Banyak } \\
\text { Jalur } \\
\text { (ken) hari) } \\
\text { Lalu } \\
\text { Lintas }\end{array}$ & $\begin{array}{l}\text { Jenis Lapis } \\
\text { Permukaan }\end{array}$ \\
\hline III C & $<50$ & $3.0-4.5$ & 1 & $\begin{array}{l}\text { Tanpa } \\
\text { nilai } \\
\text { struktural }\end{array}$ \\
\hline III B2 & $50-200$ & $3.5-4.5$ & 1 & $\begin{array}{l}\text { Tanpa } \\
\text { nilai } \\
\text { struktural }\end{array}$ \\
\hline III B1 & $201-$ & $3.5-5.0$ & 1 & $\begin{array}{l}\text { Dengan } \\
\text { nilai } \\
\text { struktural }\end{array}$ \\
\hline III A & $>500$ & $4.5-5.5$ & 2 & $\begin{array}{l}\text { Dengan } \\
\text { nilai } \\
\text { struktural }\end{array}$ \\
\hline
\end{tabular}

Jenis lapis permukaan tanpa nilai struktural dimaksudkan lapisan tersebut tidak memiliki koefisien kekuatan relatif, hanya berfungsi sebagai lapisan pelindung dan memberikan permukaan laju bagi kendaraan.

Nilai CBR tanah dasar, beban gandar standar dan tebal perkerasan.

Tabel 2. Nilai CBR tanah dasar, beban gandar standar dan tebal perkerasan Untuk Jalan Kabupaten Menurut Bina Marga

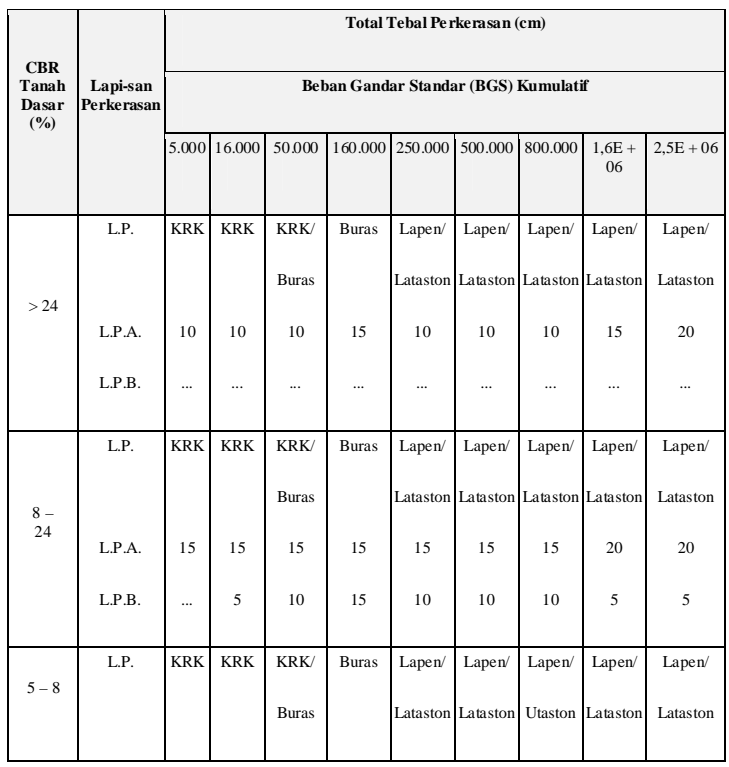

\begin{tabular}{|l|l|l|l|l|l|l|l|l|l|l|}
\hline & L.P.A. & 15 & 15 & 15 & 15 & 15 & 15 & 20 & 20 & 20 \\
& L.P.B. & 10 & 15 & 20 & 25 & 20 & 20 & 15 & 15 & 20 \\
\hline
\end{tabular}

Nilai CBR, beban gandar dan tanah dasar tambahan (urugan)

Tabel 3. Tanah Dasar Tambahan (urugan) yang disyaratkan Bina Marga

\begin{tabular}{|c|c|c|c|c|c|c|c|c|c|}
\hline \multirow{7}{*}{$\begin{array}{c}\text { Urugan Timbunan Yang Disetujui (cm) } \\
(\mathbf{X})\end{array}$} & \multicolumn{7}{|c|}{ Beban Gandar Standar (BGS) Kumulatif } \\
\cline { 2 - 11 } & $\mathbf{5 . 0 0 0}$ & $\mathbf{1 6 . 0 0 0}$ & $\mathbf{5 0 . 0 0 0}$ & $\mathbf{1 6 0 . 0 0 0}$ & $\mathbf{2 5 0 . 0 0 0}$ & $\mathbf{5 0 0 . 0 0 0}$ & $\mathbf{8 0 0 . 0 0 0}$ & $\mathbf{1 , 6 E}+\mathbf{0 6}$ & $\mathbf{2 , 5 E}+\mathbf{0 6}$ \\
\hline 4 & 5 & 5 & 5 & 5 & 5 & 5 & 5 & 10 & 5 \\
\hline 3 & 10 & 15 & 15 & 15 & 15 & 15 & 15 & 20 & 15 \\
\hline 2 & 25 & 25 & 25 & 25 & 25 & 25 & 30 & 35 & 30 \\
\hline 1.5 & 35 & 35 & 35 & 35 & 35 & 40 & 40 & 45 & 45 \\
\hline 1 & 50 & 50 & 50 & 55 & 55 & 60 & 60 & 60 & 60 \\
\hline
\end{tabular}

Lapis perkerasan kondisi visual bahan dan faktor ekivalen untuk perkerasan sisa.

Tabel 4. Faktor Ekivalensi untuk Perkerasan Sisa

\begin{tabular}{|c|c|c|}
\hline $\begin{array}{l}\text { Lapis } \\
\text { Perkerasan }\end{array}$ & Kondisi Visual Bahan & $\begin{array}{l}\text { Faktor } \\
\text { Ekivalen }\end{array}$ \\
\hline $\begin{array}{l}\text { Permukaan } \\
\text { Lataston }\end{array}$ & $\begin{array}{l}\text { Keras } \\
\text { Sangat Retak }\end{array}$ & $\begin{array}{l}2,2 \\
1,0\end{array}$ \\
\hline $\begin{array}{l}\text { Lapis Aspal } \\
\text { Beton - } \\
\text { Pondasi Atas } \\
\text { (Laston Atas) } \\
\end{array}$ & $\begin{array}{l}\text { Keras } \\
\text { Sangat Retak }\end{array}$ & $\begin{array}{l}2,0 \\
1,0\end{array}$ \\
\hline $\begin{array}{l}\text { Lapis } \\
\text { Penetrasi } \\
\text { Makadam } \\
\text { (Lapen) }\end{array}$ & $\begin{array}{l}\text { Keras } \\
\text { Memburuk atau Lama }\end{array}$ & $\begin{array}{l}1,6 \\
0,8\end{array}$ \\
\hline $\begin{array}{l}\text { Lapis Pondasi } \\
\text { Atas Agregat }\end{array}$ & $\begin{array}{l}\text { Batu Pecah Baik (CBR } \\
110 \%) \\
\text { LPA Kelas A (CBR } 80 \\
\%) \\
\text { LPA Kelas B (CBR } 60 \%)\end{array}$ & $\begin{array}{l}1,1 \\
1,0 \\
0,8\end{array}$ \\
\hline $\begin{array}{l}\text { Lapis Pondasi } \\
\text { Bawah }\end{array}$ & Keras (CBR $25 \%)$ & 0,8 \\
\hline $\begin{array}{l}\text { Lapis Pondasi } \\
\text { Atas Tanah } \\
\text { Stabilisasi } \\
\text { Semen }\end{array}$ & $\begin{array}{l}\text { Kuat dan Keras } \\
\text { Lemah }\end{array}$ & $\begin{array}{l}1,3 \\
1,1\end{array}$ \\
\hline $\begin{array}{l}\text { Lapis Pondasi } \\
\text { Atas Jenis } \\
\text { Telford }\end{array}$ & $\begin{array}{l}\text { Dipadatkan Secara } \\
\text { Individu dengan Tangan }\end{array}$ & 0,8 \\
\hline
\end{tabular}




\section{Perencanaan Tebal Perkerasan}

Perencanaan struktur perkerasan pada dasarnya menentukan tebal lapis perkerasan yang ditetapkan sedemikian sehingga menjamin bahwa tegangan-tegangan yang terjadi pada semua tingkat karena beban lalu lintas, dapat didukung pada batas-batas yang aman oleh bahan tersebut.

Metode perencanaan struktur perkerasan bagi suatu jalan dapat didasarkan pada petunjuk tebal perkerasan jalan lentur, SKBI-2.3.26. 1987, maupun dengan metode-metode lain, seperti kriteria patah untuk lalu lintas yang lebih kecil dari 50 kendaraan per hari.

Menurut Petunjuk Perencanaan Teknik untuk Jalan Kabupaten dari Direktorat Jenderal Bina Marga, Maret 2012 perencanaan untuk tebal lapis perkerasan yang telah disederhanakan ditetapkan dengan menggunakan metode dari Transport and Road Research Laboratory (TRRL) Road Note 31, yaitu metode perkerasan jalan untuk daerah tropis dan sub-tropis. Sedangkan metode Kriteria Patah digunakan dengan batas lalu lintas rencana kurang dari 5000 Beban Gandar Standar (BGS). Metode Kriteria Patah ini pada dasarnya dikembangkan pada kondisi LHR yang rendah dimana kelelahan konstruksi perkerasan sebagai akibat dari pengulangan beban tidak akan terjadi, melainkan keruntuhan mendadak sebagai akibat dari beban roda kendaraan.

Langkah pertama didalam proses perencanaan tebal perkerasan adalah penentuan umur rencana dimana perkerasan direncanakan akan memikul beban lalu lintas dalam jangka waktu tertentu.

Penetapan umur rencana ini biasanya tidak terlepas dari pertimbangan nilai-nilai ekonomis dari biaya konstruksi, rekonstruksi, pemeliharaan, dan biaya-biaya lain. Dengan kata lain tidak terlepas dari pertimbangan nilai-nilai ekonomis investasi yang dikeluarkan dalam pembangunan suatu jaringan jalan.

Sebagai contoh, jika perencanaan awal dibuat dengan meminimalkan tebal lapis perkerasan, biaya pemeliharaan akan meningkat. Sebaliknya, dengan memaksimalkan biaya konstruksi awal dengan membangun lapis perkerasan yang tebal, maka biaya pemeliharaan akan berkurang dengan sendirinya.
Sehingga untuk proyek-proyek jalan, khususnya jalan kabupaten, Bina Marga menetapkan umur rencana perkerasan berkisar antara 5 (lima) sampai dengan 10 (sepuluh) tahun.

Selanjutnya, perlu dihitung aliran lalu lintas harian dan tahunan selama jangka waktu umur rencana tersebut, dengan menggunakan jenis-jenis kendaraan dan tingkat pertumbuhan lalu lintas, agar dapat dihitung total beban sumbu gandar ekivalen kumulatif yang diperlukan untuk design struktur perkerasan.

Beban sumbu gandar ini diperhitungkan sebagai penyebab kerusakan struktur perkerasan jalan oleh lalu lintas. Beban gandar standar diambil sebesar 8160 kilogram, yang menyebabkan kerusakan struktur pada perkerasan dengan faktor kerusakan sebesar 1.00 (satu). Untuk beban-beban gandar lainnya, faktor kerusakan (angka ekivalen terhadap beban gandar standar) digunakan hukum pangkat 4 (empat) dari beban gandar standar. Sebagai acuan dalam menentukan tingkat pertumbuhan lalu lintas tahunan dapat dipergunakan nilai-nilai sebagai berikut, yang diperoleh dari hasil studi mengenai lalu lintas.

$\begin{array}{ll}\text { Pulau Jawa, Bali } & 3,0 \% \\ \text { Pulau Sumatera } & 4,5 \% \\ \text { Pulau Sulawesi } & 4,8 \% \\ \text { Pulau Kalimantan } & 5.6 \% \\ \text { Pulau Irian } & 6,0 \%\end{array}$

Perlu dipertimbangkan pula prosentasi kendaraan berat yang didefinisikan sebagai semua kendaraan dengan berat total lebih dari 5 (lima) ton. Hal ini disebabkan kerusakan yang ditimbulkan oleh kendaraan berat terhadap struktur perkerasan mempunyai nilai yang sangat besar dibandingkan dengan kendaraan ringan.

Untuk tujuan perencanaan tebal lapis perkerasan jalan Kabupaten, kelas rencana lalu lintas (KRL) dalam beban gandar standar kumulatif dengan memperhitungkan prosentasi kendara-an berat adalah sebagai mana terlampir pada Tabel 5. dibawah ini: 
Tabel 5. Kelas Rencana Lalu Lintas untuk Desain Lapis Perkerasan

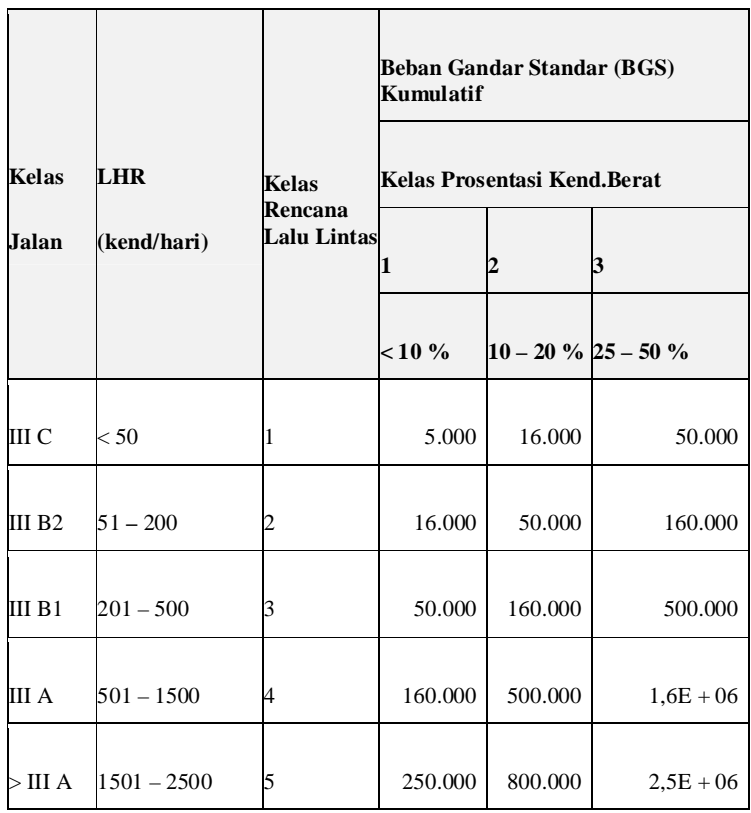

Sebagai tambahan, kelas rencana yaitu kelas 5 disediakan bagi jalan Kabupaten dengan tingkat lalu lintas yang tinggi.

Dalam penentuan kekuatan daya dukung tanah dasar, nilai-nilai CBR sangatlah diperlukan. Seperti yang telah disebutkan sebelumnya, CBR tersebut ditentukan melalui test laboratorium untuk perkerasan jalan baru, dan test lapangan untuk pekerjaan peningkatan jalan.

Untuk penyederhanaan perhitungan perencanaan, CBR tanah dasar dapat diklasifikasikan sebagai berikut.

\begin{tabular}{|c|c|}
\hline Nilai CBR & Kualifikasi \\
\hline $2 \%-3 \%$ & Amat buruk \\
\hline $3 \%-5 \%$ & Buruk \\
\hline $5 \%-8 \%$ & Sedang \\
\hline $8 \%-24 \%$ & Baik \\
\hline$\geq 24 \%$ & Amat baik \\
\hline
\end{tabular}

Berdasarkan data akhir CBR desain untuk tanah dasar, dan berdasarkan kelas rencana lalu lintas dalam beban gandar standar (BGS), maka tebal perkerasan baru untuk setiap segmen jalan dapat ditentukan dengan menggunakan pedoman untuk perenca-naan tebal lapis perkerasan yang telah disederhanakan oleh Bina Marga. Tebal perkerasan yang disyaratkan terlihat pada Tabel 2 .

Jika ternyata nilai-nilai CBR untuk desain lebih kecil dari 5\%, maka diperlukan urugan timbunan yang dipadatkan sampai mencapai CBR sebesar 5\%. Selanjutnya dibuat tebal perkerasan dengan menggunakan nilai CBR 5\% tersebut.

Tebal urugan timbunan yang disyaratkan oleh Bina Marga seperti pada Tabel 3.3 tergantung dari nilai CBR yang ada dan kelas rencana lalu lintas.

Untuk pekerjaan peningkatan jalan khususnya perencanaan tebal perkerasan tambahan, tebal tersebut dapat ditentukan dengan mengurangkan tebal perkerasan sisa pada perkerasan yang ada dari total perkerasan yang diperlukan. Tebal perkerasan sisa yang ada ditentukan dengan suatu faktor sisa yang diperoleh melalui penaksiran kualitas dari setiap lapis perkerasan yang ada.

Faktor-faktor perkerasan sisa tersebut seperti pada Tabel 4. dari lampiran.

\section{Bahan Konstruksi Jalan}

Dalam keilmuan bahan jalan, banyak terdapat jenis-jenis material yang dipergunakan sebagai bahan lapis perkerasan. Material lapis perkerasan pada dasarnya ditentukan berdasarkan pertimbangan-pertimbangan kualitas bahan dan pengadaan dana.

Bina Marga dalam hal ini telah menetapkan jenis-jenis material lapis perkerasan untuk jalan Kabupaten yang dipertimbangkan berdasarkan kebutuhan jalan tersebut.

Material lapis permukaan dapat diklasifikasikan menurut jumlah lalu lintas harian rata-rata (LHR). Untuk LHR yang lebih kecil dari 50 kendaraan/hari digunakan lapis pelindung berupa kerikil atau pasir. Untuk LHR antara 50 sampai dengan 500 kendaraan/hari digunakan lapis pelindung berupa Buras, Burtu, atau Burda. Sedangkan untuk LHR yang lebih besar dari 500 kendaraan/hari digunakan lapisan penetrasi (Lapen) atau lapisan tipis aspal beton (Lataston).

Untuk semua nilai LHR, lapis pondasi atas dapat dipilih dari agregat (batu) pecah bergradasi dengan ukuran maksimum butir $50 \mathrm{~mm}$ dan CBR minimum 60\%, atau makadam ikat basah dengan ukuran butir maksimum $75 \mathrm{~mm}$ dan CBR minimum $55 \%$. 
Lapis pondasi bawah dapat dipilih dari kerikil, pasir, lempung campuran, atau tanah yang distabilisasi dengan ukuran butir atau partikel maksimum $75 \mathrm{~mm}$ dan CBR min $25 \%$.

\section{Lunak}

\section{Perencanaan Pada Kondisi Tanah}

Sering dijumpai bahwa suatu jalan dilaksanakan pada kondisi tanah yang lunak. Kondisi tanah tersebut dengan sendirinya menghasilkan kekuatan daya dukung tanah yang rendah. Disamping itu pula jalan yang dibangun pada tanah yang lunak menimbulkan permasalahan tanah seperti: penurunan dan keruntuhan atau longsor jika tanah asli atau tanah pendukung tidak cukup kuat untuk menahan beban berat di atasnya. Kondisi sedemikian haruslah diperhitungkan secara seksama agar diperoleh suatu perkerasan jalan yang baik.

Pada umumnya untuk mengatasi hal tersebut di atas diperlukan perbaikan tanah dasar yang bertujuan untuk meningkatkan daya dukung tanah tersebut. Dalam pencapaian tujuan tersebut perlulah diadakannya studi lapangan yang khusus dan sederhana dengan mengidentifikasikan daerah-daerah sesuai dengan permasalahan-nya, dilanjutkan dengan pemilihan metode konstruksi yang efektif yang sesuai dengan kondisi setempat.

Banyak cara untuk memperbaiki kondisi tanah tersebut, baik secara modem maupun cara tradisionil. Sebagai bahan pertimbangan, perbaikan tanah tersebut dapat dilakukan antara lain dengan:
a. Stabilisasi tanah dengan semen atau kapur
b. Drainase vertikal, jika terjadi penurunan
c. Penggunaan Geotekstil, jika terjadi keruntuhan setempat
d. Pemancangan cerucuk kayu panjang secara vertikal, jika stabilitas timbunan kurang stabil
e. Penggunaan tikar dari bronjong kayu, jika terjadi keruntuhan setempat

\section{KESIMPULAN DAN SARAN}

\section{Kesimpulan}

Dari uraian tersebut di atas terlihat bahwa pentingnya suatu perencanaan perkerasan jalan yang disesuaikan dengan tingkat kebutuhan lalu lintas, keadaan tanah, maupun penyediaan pembiayaan, yang pada akhirnya tercapainya suatu penanganan jalan khususnya jalan Kabupaten yang terselenggara secara efisien dan secara teknik dapat dipertanggungjawabkan, dengan kesesuaian pada kondisi lingkungan setiap Kabupaten. Petunjuk teknis ini dari instansi terkait dan referensi bidang studi terkait pembangunan jalan.

\section{Saran}

Untuk pencapaian tujuan tersebut, diharapkan dari pihak Kabupaten setempat dapat membina para teknisi setempat dalam meningkatkan kemampuannya agar dapat berperan dalam proses pembangunan khususnya perencanaan perkerasan jalan. Pihak pelaksana hendaknya juga turut membina diri dalam membantu program tersebut. Pada akhirnya, kerja sama antara berbagai pihak yang terkait sangatlah diperlukan.

\section{DAFTAR PUSTAKA}

Bina Marga, 2012, Petunjuk Teknik Survey dan Perencanaan Teknik Jalan Kabupaten, Departemen Pekerjaan Umum.

Bina Marga, 2007, Petunjuk Perencanaan Tebal Perkerasan Lentur Jalan Raya dengan metode Analisa Komponen, SKBI 2.3.26.2007, Departemen Pekerjaan Umum, Jakarta.

Bina Marga, 2008, Pedoman Teknis Penyusunan Design Jalan Kabupaten yang sudah ada, Departemen Pekerjaan Umum.

Hanafi, 2003. Comparative Study of Flexible Pavement Designs in Great Britain and Indonesia, M.Sc. Dissertation, unpublished.

Salem P. Sihombing, 2011, Stabilisasi Tanah, Seminar Road Engineering Modul II, Ikatan Nasional Konsultan Indonesia, Jakarta. 